Volume 1, Nomor 1, Desember 2019

\title{
VALIDITAS HANDOUT BERBENTUK KOMIK FISIKA BERBASIS PROBLEM BASED LEARNING UNTUK MENINGKATKAN KETERAMPILAN BERPIKIR KREATIF PESERTA DIDIK
}

\author{
Desrianti Sahida \\ STKIP Muhammadiyah Sungai Penuh \\ e-mail: dessabki14@gmail.com
}

\begin{abstract}
ABSTRAK
Mengacu kepada UU Sistem Pendidikan Nasional No. 20 tahun 2003 tentang usaha sadar dan terencana seorang guru untuk mewujudkan suasana belajar dan proses pembelajaran agar peserta didik secara aktif mengembangkan potensi, usaha yang bisa dilakukan adalah mengembangkan handout berbentuk komik fisika yang valid sebagai inovasi bahan ajar dalam upaya mengembangkan potensi peserta didik berupa keterampilan berpikir kreatif, sehingga penyajian materi dan tugas dalam handout berbentuk komik fisika sesuai dengan sintak problem based learning. Tujuan dari penelitian ini adalah untuk mengembangkan handout berbentuk komik berbasis problem based learning untuk meningkatkan keterampilan berpikir kreatif peserta didik dan mengetahui kriteria validitasnya. Jenis penelitian adalah research and development dengan model pengembangan Four-D. Validitas Handout berbentu komik diperoleh dari hasil validasi menggunakan lembar validasi ahli oleh 3 orang ahli. Hasil penelitian menunjukkan bahwa validitas isi handout berbentuk komik mendapat nilai $86,4 \%$ dengan kriteria valid, validitas konstruksi mendapat nilai 90,1\% dengan kriteria valid, dan validitas bahasa 91,6\% dengan kriteria valid. Handout berbentuk komik fisika berbasis problem based learning berhasil dikembangkan dengan kriteria validitas valid diharapkan dapat menjadi bahan ajar yang bermutu dan inovatif untuk membantu meningkatkan ketermpilan berpikir kreatif peserta didik.
\end{abstract}

Kata Kunci: Validitas, Handout Berbentuk Komik, Fisika, Problem Based Learning

Jurnal Edu Research

Indonesian Institute For Corporate Learning And Studies (IICLS)

Page 12 


\section{PENDAHULUAN}

Pendidikan mempunyai peranan yang sangat menentukan bagi perkembangan dan perwujudan diri individu, terutama bagi pembangunan bangsa dan Negara. Kemajuan suatu negara bergantung kepada cara negara tersebut mengenali, menghargai, memanfaatkan sumber daya manusia dalam hal ini berkaitan erat dengan kualitas pendidikan yang diterima oleh masyarakat. Pada kenyataannya kualitas pendidikan yang di terima oleh masyarakat di Negara Indonesia dalam kategori rendah. Hal ini terlihat dari hasil pembelajaran peserta didik.

Pembelajaran seorang peserta didik dapat dikatakan tuntas dan berhasil apabila nilai yang diraih peserta didik mencapai kriteria ketuntasan monimal (KKM). Berdasarkan hasil observasi di salah satu sekolah di Indonesia yaitu di MAN Sebukar Kabupaten Kerinci Provinsi Jambi Indonesia terlihat perolehan kompetensi peserta didik belum sepenuhnya mencapai kriteria ketentuan minimal (KKM) seperti yang terlihat pada Tabel 1.

\section{Tabel 1. Rata-rata Nilai Harian Fisika Materi Gerak Lurus dengan Kecepatan dan Percepatan Konstan Peserta Didik Kelas X IPA 2 Semester 1 MAN Sebukar Tahun Ajaran 2015/2016}

\begin{tabular}{|l|l|l|l|}
\hline No & Aspek & Materi \\
\cline { 3 - 4 } & & $\begin{array}{l}\text { Gerak Lurus } \\
\text { Dengan Kecepatan } \\
\text { Konstan }\end{array}$ & \begin{tabular}{l} 
Gerak $\begin{array}{l}\text { Dengan } \\
\text { Percepatan } \\
\text { Konstan }\end{array}$ \\
\hline 1
\end{tabular} Nilai Rata-rata peserta didik yang \\
\hline 2 & $\begin{array}{l}\text { Jumlah } \\
\text { mencapai KKM }\end{array}$ & 52 & 51,6 \\
\hline 3 & $\begin{array}{l}\text { Jumlah peserta didik yang tidak } \\
\text { mencapai KKM }\end{array}$ & 13 & 7 \\
\hline 4 & Jumlah peserta didik & 22 & 15 \\
\hline 5 & Persentase ketuntasan & $40,9 \%$ & $31,8 \%$ \\
\hline 6 & Persentase ketidaktuntasan & $59,1 \%$ & $68,2 \%$ \\
\hline
\end{tabular}

(Sumber: Guru Fisika kelas X IPA 2 MAN Sebukar)

Rendahnya perolehan kompetensi peserta didik disebabkan rendahnya kategori keterampilan berpikir kreatif peserta didik. Berdasarkan hasil analisis karakter peserta didik terlihat keterampilan berpikir kreatif yang dimiliki peserta didik kelas X IPA 2 MAN Sebukar berada pada kategori rendah. Hal ini terlihat dari skor yang dicapai peserta didik kelas X IPA 2 MAN Sebukar pada setiap indikator keterampilan berpikir kreatif rata-rata kecil dari $60 \%$ seperti pada Gambar 1. 


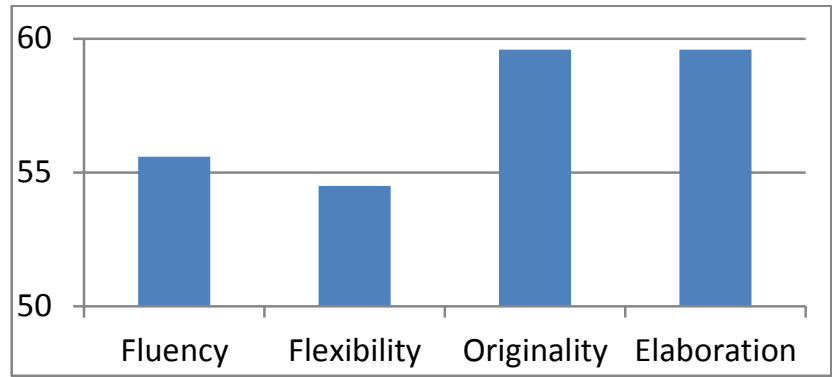

\section{Gambar 1. Persentase indikator keterampilan berpikir kreatif peserta didik kelas X IPA 2 MAN Sebukar}

Dari Gambar 1 terlihat skor yang didaapat pada indikator fluency adalah 55,6\%, skor yang didapat pada indikator flexibility adalah 54,5\%, skor yang didapat pada indikator originality adalah 59,6\%, dan skor yang didapat pada indikator elaboration adalah 59,6\%, salah satu sub indikator dengan skor terendah adalah lancar dalam mengemukakan ide mengenai pemecahan masalah dari indikator fluency yaitu dengan skor 47,7\%, skor rata-rata keseluruhan indikator keterampilan berpikir kreatif adalah 58,7\%. Keterampilan berpikir kreatif dapat ditingkatkan melalui pemilihan model pembelajaran berbasis masalah. Utecht (2003) menjelaskan bahwa :

Problem Based Learning (PBL) atau pembelajaran berbasis masalah adalah pendekatan yang tidak hanya melibatkan peserta didik sebagai peserta aktif dan kreatif dalam proses pembelajaran tetapi mendorong mereka untuk memiliki peran aktif dan kreatif dengan melibatkan mereka secara bermakna dengan permasalahan dunia nyata.

Dengan melibatkan peserta didik secara aktif dan kreatif dalam proses pembelajaran akan memberikan pengalaman dan pengetahuan baru yang lebih bermakna bagi peserta didik melalui pemecahan masalah-masalah yang ada dunia nyata, hal ini dapat mendorong dan meningkatkan keterampilan berpikir kreatif peserta didik. Sehingga dapat dinyatakan bahwa untuk permasalahan di kelas X IPA 2 MAN Sebukar yaitu rendahnya keterampilan berpikir kreatif peserta didik dapat ditingkatkan dengan menerapkan model pembelajaran Problem Based Learning $(P B L)$ dalam proses belajar dan mengajar. Model pembelajaran yang diterapkan dalam proses pembelajaran akan lebih bermakna apabila menggunakan bahan ajar yang tepat.

Dalam UU Sistem Pendidikan Nasional No. 20 tahun 2003 dijelaskan bahwa:

Pendidikan merupakan usaha sadar dan terencana untuk mewujudkan suasana belajar dan proses pembelajaran agar peserta didik secara aktif mengembangkan potensi dirinya untuk memiliki kekuatan spiritual keagamaan, pengendalian diri, kepribdian, kecerdasan, akhlak mulia serta keterampilan yang diperlukan dirinya, masyarakat, bangsa, dan negara.

Jurnal Edu Research

Indonesian Institute For Corporate Learning And Studies (IICLS) 
Usaha yang dapat dilakukan adalah mengembangkan bahan ajar salah satunya adalah handout yang inovatif. Menurut Lia (2016) handout terdiri dari judul, kompetensi inti, kompetensi dasar, indikator pencapaian kompetensi, tujuan pembelajaran, uraian materi, dan penilaian. Salah satu isi dari handout adalah pencapaian kompetensi, dengan demikian maka handout harus diturunkan dari kurikulum. Handout merupakan salah satu bentuk media cetak yang mudah dikembangkan dan dapat dimanfaatkan dalam pembelajaran.

Handout yang menarik dapat memberikan manfaat yang besar dalam pembelajaran, dengan handout yang menarik peserta didik akan termotivasi untuk berpartisipasi dalam proses pembelajaran. Komik merupakan bacaan yang digemari oleh anak-anak, remaja, dan dewasa. Lubis (2009) menyatakan bahwa :

Komik adalah serial kartun yang berupa cerita dan mempunyai naskah pembicaraan antar pelaku yang dituliskan dekat kepalanya pada daerah putih yang disebut balloons. Komik selalu identik dengan gambar, selain itu komik juga memiliki jiwa dan raga.

Jiwa komik yang dimaksud adalah tema, cerita, tokoh, dan latar/setting dan raga komik yang dimaksud adalah ilustrasi yang merupakan unsur dominan dalam sebuah komik. Ilustrasi dalam komik dikatakan komunikatif bila mampu menyampaikan keutuhan cerita, menunjukkan urutan kejadian, membangkitkan emosi, dan menciptakan suasana. Dengan begitu permasalahan dunia nyata yang berhubungan dengan konsep Fisika dapat dituangkan dalam alur cerita pada komik yang akan dikembangkan. Ningsih (2011) menjelaskan bahwa:

Alur cerita yang runtut dan teratur dalam komik memudahkan diingat kembali sehingga peserta didik tertarik untuk membacanya. Minat akan timbul jika peserta didik tertarik oleh sesuatu yang dibutuhkan atau yang dipelajari bermakna bagi dirinya.

Sehingga handout berbentuk komik dapat digunakan dalam proses pembelajaran. Dengan menggunakan handout berbentuk komik dalam pembelajaran diharapkan peserta didik termotivasi dalam belajar sehingga peserta didik dapat memahami konsep pada materi pelajaran yang diajarkan dengan mudah. Memotivasi peserta didik dipandang sebagai aspek penting dalam pembelajaran yang efektif. Ketika peserta didik kurang tertarik terhadap pelajaran maka akan mempengaruhi cara peserta didik bereaksi atau memperhatikan guru. Negrete (2013) menjelaskan bahwa:

Bahan bacaan yang ringan menjadi sumber bacaan yang digemari seperti tabloid gosip, majalah bisnis, majalah fashion, dan komik. Saat ini komik merupakan alat komunikasi yang disukai berbagai kalangan masyarakat dengan cara menyajikan pokok bacaan yang menarik, sehingga menjadi sarana yang sangat baik digunakan dalam proses pembelajaran bertujuan untuk mengkomunikasikan materi pelajaran. 
Sehingga handout berbentuk komik menjadi sumber pemikiran penulis disebabkan komik selain disukai oleh anak-anak, komik juga banyak disukai oleh orang dewasa. Selain itu komik juga memiliki gambaran dan teks yang lebih menarik sehingga peserta didik lebih mudah memahami materi yang terkandung di dalam komik tersebut.

Untuk mengetahui layak atau tidaknya handout yang dikembangkan handout tersebut harus melalui beberapa tahap pengujian salah satunya adalah uji validitas. Validitas adalah suatu standar ukuran yang menunjukkan ketepatan dan kesahihan suatu instrument, suatu tes dikatakan valid apabila tes tersebut mengukur apa yang hendak diukur. Tes memiliki validitas yang tinggi jika hasilnya sesuai dengan kriteria, dalam arti memiliki kesejajaran antara tes dan kriteria.

Sisi lain dari pengertian validitas adalah aspek kecermatan pengukuran. Suatu alat ukur yang valid tidak hanya mampu menghasilkan data yang tepat akan tetapi juga harus memberikan gambaran yang cermat mengenai data tersebut. Cermat berarti bahwa pengukuran itu dapat memberikan gambaran mengenai perbedaan yang sekecil- kecilnya di antara subjek yang satu dengan yang lain.

Uji validitas dilakukan untuk mengetahui tingkat kesahihan instrumen yang digunakan. Sebuah instrumen dikatakan valid apabila mampu mengukur apa yang diinginkan dan dapat mengungkapkan data dari variabel-variabel yang diteliti secara tepat.

\section{METODE PENELITIAN}

Penelitian ini merupakan penelitian pengembangan (research and the development). Pengembangan handout berbentuk komik berbasis problem based learning ini menggunakan model Four-D (4-D), yang dikemukakan oleh Thiagrajan (1974). Model pengembangan 4-D terdiri dari 4 tahap yaitu Define (pendefinisian), Design (perancangan), Develop (pengembangan), dan Disseminate (penyebaran).

Thiagarajan (1974) membagi tahap pengembangan dalam dua kerja yaitu : expert appraisal dan developmental testing. Expert appraisal merupakan teknik untuk memvalidasi atau menilai kelayakan rancangan produk. Dalam kerja ini dilakukan evaluasi oleh ahli dalam bidangnya. Saran-saran yang diberikan digunakan untuk memperbaiki materi dan rancangan pembelajaran yang telah disusun. Developmental testing merupakan kerja uji coba rancangan produk pada sasaran subjek yang sesungguhnya. Pada saat uji coba ini dicari data respon, reaksi atau komentar dari sasaran pengguna handout. Hasil uji coba digunakan memperbaiki produk. Setelah produk diperbaiki kemudian diujikan kembali sampai memperoleh hasil yang efektif.

Dalam konteks pengembangan handout berbentuk komik ini, tahap pengembangan dilakukan dengan cara menguji isi dan keterbacaan handout tersebut kepada pakar yang terlibat 
pada saat validasi rancangan. Validasi handout berbentuk komik ini dilakukan oleh 3 (tiga) orang tim ahli sesuai dengan bidang dan kajiannya masing-masing. Hasil pengujian kemudian digunakan untuk revisi sehingga handout tersebut benar-benar telah memenuhi kebutuhan pengguna.

Penggunaan perhitungan data nilai akhir hasil angket dianalisis dalam analisis deskriptif yang menggambarkan validitas handout berbentuk komik fisika berbasis Problem Based Learning. Analisis validitas menggunakan rumus Aiken's V yaitu:

$$
V=\frac{\sum s}{[n(c-1)]}
$$

Keterangan :

$$
\begin{array}{ll}
s & =\mathrm{r}-\mathrm{lo} \\
\text { lo } & =\text { Angka penilaian validitas yang terendah } \\
c & =\text { Angka penilaian validitas yang tertinggi } \\
r & =\text { Angka yang diberikan oleh seorang penilai } \\
n & =\text { Jumlah penilai }
\end{array}
$$

(Azwar, 2015)

Kategori validitas asesmen kinerja berdasarkan nilai akhir yang diperoleh dapat dilihat pada Tabel 2.

\section{Tabel 2. Kategori validitas produk}

\begin{tabular}{|c|c|}
\hline Tinkat pencapaian & Kategori \\
\hline$\geq 0,6$ & Valid \\
\hline$<0,6$ & Tidak valid \\
\hline
\end{tabular}

(Azwar, 2015)

\section{HASIL DAN PEMBAHASAN}

Validasi handout berbentuk komik didasarkan pada butir-butir instrument validasi ahli berdasarkan langkah-langkah penyusunan handout berbentuk komik, maka dihasilkan handout berbentuk komik fisika berbasis problem based learning. Handout tersebut selanjutnya divalidasi oleh para ahli. Validitas handot berbentuk komik meliputi validitas isi, konstruksi, dan bahasa. Validator yang dilibatkan pada proses validasi ini adalah Bapak Dr. Darmansyah, ST, M.Pd, Bapak Dr. Hamdi, M.Si, dan Bapak Dr. Ramli, M.Si. 
Validitas handout berbentuk komik fisika berbasis problem badsed learning diperoleh dari hasil validasi menggunakan lembar validasi ahli meliputi kesesuaian handout berbentuk komik fisika dengan sintak problem based learning, dan kesuaiannya dengan Kompetensi Dasar materi Fisika yaitu materi Gerak Lurus. Nilai validitas isi handout berbentuk komik mendapat nilai $86,4 \%$ dengan kriteria valid menunjukan bahwa penyampaian materi dalam handout berbentuk komik mempunyai karakteristik yang sesuai dengan sintak problem based learning yang dijelaskan oleh Ranine dan Symsons (2005) yaitu:

a) Menemukan masalah

b) Mengembangkan struktur kerja

c) Menetapkan masalah

d) Mengumpulkan berbagai informasi

e) Menemukan solusi

f) Menentukan solusi terbaik

g) Menyajikan solusi.

dengan langkah tersebut dapat memunculkan indikator keterampilan berpikir kreatif peserta didik sesuai dengan Greenstein (2012) sebagai berikut:

a) Fluency

b) Flexibility

c) Originality

d) Elaboration

sementara validitas konstruksi mendapat nilai 90,1\% dengan kriteria valid menunjukan bahwa handout telah disusun dengan inovasi yang baik, dan dapat menarik dan memotivasi peserta didik, dan validitas bahasa 91,6\% dengan kriteria valid menyatakan bahwa pemilihan bahasa dalam handout berbentuk komik telah menggunakan bahasa sesuai dengan EYD dan tidak mengandung makna ganda.

Selain divalidasi isi, kontruksi, dan bahasa. Handout berbentuk komik tersebut dinilai dari komponen yang ada di dalam handout. Dimana komponen-komponennya adalah sebagai berikut:

1. Identitas handout Identitas handout dengan kategori valid menunjukkan bahwa identitas dalam handout telah dituliskan secara jelas.

2. Kompetensi Inti dan Kompetensi Dasar

Kompetensi Inti dan Kompetensi Dasar dengan kategori valid menunjukkan bahwa telah sesuai antara kompetensi inti dan kompetensi dasar yang di pilih dengan penyajan materi dalam handout. 
3. Indikator Pencapaian Kompetensi Indikator pencpaian kompetensi dengan kategori valid menunjukkan bahwa telah sesuai antara kompetensi inti, kompetensi dasar, dan indikator pencapaian tujuan yang di pilih dengan penyajan materi dalam handout.

4. Tujuan Pembelajaran

Tujuan pembelajaran dengan kategori valid menunjukkan bahwa telah sesuai antara kompetensi inti, kompetensi dasar, indikator pencapaian tujuan, dan tujuan pembelajaran yang di pilih dengan penyajan materi dalam handout.

5. Menggunakan sintak $P B L$

Menggunakan sintak PBL dengan kategori valid menunjukkan bahwa langkah-langkah pembelajaran menggunakan handout berbentuk komik ini sesuai dengan sintak PBL. Dengan sintak PBL handout berbentuk komik tersebut dapat meningkatkan keterampilan berpikir kreatif peserta didik.

6. Materi Ajar

Materi ajar dengan kategori valid menunjukkan bahwa telah sesuai antara kompetensi inti, kompetensi dasar, indikator pencapaian tujuan, dan tujuan pembelajaran yang di pilih dengan materi yang akan diajarkan menggunakan bahan ajar handout berbentuk komik fisika.

7. Latihan Soal

Latihan soal dengan kategori valid menunjukkan bahwa telah sesuai antara kompetensi inti, kompetensi dasar, indikator pencapaian tujuan, dan tujuan pembelajaran yang di pilih dengan latihan soal yang terdapat di dalam handout.

Setiap indikator terkait validitas mendapatkan penilaian sangat valid seperti yang telah diuraikan di atas. Perhitungan nilai validitas secara keseluruhan mencapai nilai 89,7\% dengan kriteria valid, sehingga dapat disimpulkan bahwa validitas Handout berbentuk komik Fisika mempunyai kriteria sangat valid untuk digunakan sebagai bahan ajar yang mampu mendorong peserta didik aktif dalam pembelajaran, mendukung pemecahan masalah, mendorong peserta didik bekerjasama dalam kelompok dan meningkatkan keterampilan berpikir kreatif peserta didik dalam mempelajari materi gerak lurus dengan kecepatan dan percepatan konstan. 


\section{KESIMPULAN}

Berdasarkan hasil penelitian dan pembahasan dapat disimpulkan bahwa bahan ajar dalam pembelajaran Gerak Lurus dengan Kecepatan dan Percepatan Konstan telah berhasil dibuat dalam bentuk handout berbentuk komik Fisika berbasis Problem Based Learning. Validitas handout berbentuk komik fisika sebagai inovasi dengan memasukkan aspek-aspek yang perlu dimasukan dalam mendukung pembelajaran bermodel Problem Based Learning. handout berbentuk komik Fisika berbasis Problem Based Learning yang dikembangkan memiliki validitas valid ditinjau dari validitas isi, validitas konstruksi, dan validitas bagasa sehingga dapat digunakan dalam pembelajaran untuk membantu peserta didik mencapai kompetensi dasar gerak lurus dengan sasaran untuk meningkatkan keterampilan berpikir kreatif peserta didik.

\section{UCAPAN TERIMA KASIH}

Ucapan terima kasih kepada Ibu Prof. Dr. Festiyed, M.S dan Yohandri, S.Si, M.Si, Ph.D sebagai dosen pembimbing dan memberikan motivasi kepada penulis dalam penulisan jurnal ini.

\section{DAFTAR PUSTAKA}

Greenstein. 2012. Assessing 21st Century Skill A Guide To Evaluating Mastery and Authentic Learning. Jurnal United States Of America : Corwin. Vol. 3, (Diakses 14 April 2016)

Lubis. 2009. Depresi Tinjauan Psikologis. Jakarta: Kencana Prenada Media Group.

Sari, Lia Purnama. 2016. Pengembangan Bahan Ajar Multimedia Interaktif Berbasis Kemampuan Berpikir Kreatif Melalui Problem Based Learning (PBL) Pada Materi Indra Penglihatan dan Alat Optik SMP. Padang : Universitas Negeri Padang

Symons, dan Raine. 2005. Possibilities a Practice Guide to Problem Based Learning in Physics and Astronomi. Jurnal England : University Of Hull. Vol. 3, (Diakses 14 April 2016)

Thiagrajan. 1974. Instructional Development For Training Teachers Of Exceptional Children. Indiana : Indiana University Bloomington. 